\title{
EFFECT OF PLANTING DATES AND PERIODS OF CURING ON QUANTITATIVE, QUALITATIVE CHARACTERISTICS AND STORAGE ABILITY OF TWO GARLIC CULTIVARS
}

\author{
Hassan $^{1}$ G.H, M.A. El-Shal' ${ }^{2}$ KH.A. Soliman ${ }^{3}$, I.M Ghoneim ${ }^{4}$ \\ ${ }^{1,3}$ Sabhia Research Station, Agricultural Researcher Center ,Giza, \\ Egypt, ${ }^{2,4}$ Department of vegetable crops, faculty of Agriculture, \\ Alexandria University, Alexandria, Egypt
}

\begin{abstract}
Two field experiments were carried out during the winter seasons of 2013/2014,2014/2015 at the Agricultural Experimental Station Farm (at Abies), Faculty of Agriculture, Alexandria university, to investigate the effect of planting dates $\left(10^{\text {th }}\right.$ of September, $1^{\text {st }}$ of October and $20^{\text {th }}$ of October) on vegetative growth characters, yield and its components, quality characteristics and storability of two garlic cultivars (Balady and Sids-40). Early planting dates $\left(10^{\text {th }}\right.$ of September and $1^{\text {st }}$ of October), gave the highest plant height, number of leaves and plant weight. Also, recorded higher mean values of bulb yield and its components ,i.e., bulb weight, cloves weight (endow, External) , number of cloves per bulb, bulb diameter, neck diameter and bulbing ratio) of the two tested garlic cultivars than the late planting date ( $20^{\text {th }}$ of October), in both seasons. Results indicated significant differences between the two tested cultivars , where, Balady cultivar had higher plant height , more number of cloves head-1, thicker neck diameter and higher bulbing ratio than Sids-40, which recorded higher mean values for number of leaves and plant weight as well as head bulb weight, and bulb diameter. Based on the obtained results, early planting date on 10th of September is recommended for achieving better vegetative growth and higher bulb yield and its components of the garlic plants, particularly, Sids-40 under the environmental conditions prevailing in Alexandria Governorate. Minimum weight loss was recorded with curing for 21 days . Sids-40 was superior in this respect
\end{abstract}

\section{INTRODUCTION}

Garlic (Allium sativum L., Alliaceae) has been playing one of the most important dietary and medicinal roles for human beings. Egypt ranks the fourth leading country in the world for garlic production (244.626 MT) after China, India and Korea FAO( 2011; Abou EI-Magd et al. 2012). The major production of garlic in Egypt is obtainable usually during the months of April and May, but the optimum export window to European Countries is the period from March up to mid April. The early production during this period 
represents a vital importance, since the demand for either export or local market is high and the prices are high as well which affects the net income of garlic production. Nowadays, in Egypt, a great attention is given for promoting garlic production to satisfy the increased demands of local fresh market, developing processing industry and rapidly growing exportation. From the economical stand point, more efforts should be directed towards increasing yield per unit area and improving head quality characteristics. These goals can be achieved by a combination of inputs, such as, using the suitable cultivar and the appropriate planting dates, cultural practices, handling and post-harvest conditions including the period of correct curing.

Planting date has a pronounced influence on plant development, growth, and marketable yields of garlic plants. Rahim et al.( 1984) and Das et al. (1985) revealed that plant height, number of cloves /bulb ,bulb diameter . bulb clove weight, yield (ton/fed.) were higher at early planting date for the white garlic genotype (Clone 24) followed by Egyptian (Balady cultivar). Growth stage require short days while, the bulbing stage of garlic is enhanced by long days Qaryouti and Kasrawi (1995). Ali and ElSayed (1999), evaluated the effect of different planting dates and varieties on garlic bulb yield and quality attributes, and their results indicated that early planting on $22^{\text {th }}$ Oct .gave the highest bulb yields of large bulbs over the two seasons for the $22^{\text {th }}$ of October , $7^{\text {th }}$ of November, $22^{\text {th }}$ of November , and $7^{\text {th }}$ December. Yield decreased consistently with delayed planting. The performance of garlic plants depends on the time of planting as the vegetative growth is encouraged under short day and cool temperature , meanwhile, long day and high temperatures are favorable for better bulb development Subrata et al. (2010). The main phonological stages of garlic are the number of days from planting to emergence ; emergence to bulb formation, clove sprouting ,leafing ,bulb initiation and maturation Swati Barche et al. (2013). El-Zohiri and Farag (2014) found that sowing on October $10^{\text {th }}$, gave higher yield components than late planting. Also, the lowest yield and higher disease percentage, incidence of leaf blight, was scored at the late planting with all tested genotypes. Therefore, they concluded that the white garlic (Balady and clone 24 ) must be planted early on the mid of September (7-10th), while colored genotypes (Sids-40 and Egaseed 1) could be planted on the mid of October under El-Minia Governorate conditions. Moreover, cultivar Egaseed -1 ranked the first for whole plant weight ,bulb weight, clove weight, yield as ton/fed Youssef and Tony (2014). Al-Otayk et al. (2008), found that Balady cultivar produced more cloves number compared with 
the Chinese one while Chinese cultivar gave the highest mean value for bulb diameter over Balady cultivar, and it could be concluded that, the largest total yield was achieved owing to the increase in number of cloves /bulb than clove weight. Nevertheless; Noorbakhshian et al. (2008), evaluated some agronomic traits related to yield components for several garlic cultivars and reported that cloves weight had maximum positive effect on the yield characters.

Curing is a fancy word for properly drying bulbs such as garlic and onions . A good cure improves the flavor, storage quality and hardness of both garlic and perennial onion bulbs. The goal of this process is to dry the outer wrapper layers completely while keeping both bulbs or cloves plump and deliciously aromatic and generally this process takes from two weeks up to two months. Many factors influence the rate of curing such as humidity, temperature, air circulation, size of bulbs and the number of green leaves at harvest. So, the bulbs should get enough space, good ventilation and complete protection from rain Jauron and Wallace (2014). Yang and Lee (2000) found that non-cured sample of garlic showed rapid increase of carbon dioxide production after 50 days of storage, and this might be related to incidence of fungal decay. On the other hand, drying too quickly can cause bulbs to shrivel and do not store well, so, the bulbs should be dried out away from direct sunlight and extreme heat. They recommended the beneficial effect of curing for three months at $25^{\circ} \mathrm{C}$ which lead to maintenance of low water content in garlic bulbs, which resulted in reduction of decay. Moreover, during the course of curing, the bulbs should be checked to remove any spoiled ones taking care of being careful when handling the bulbs as little as possible to avoid mechanical damage to the bulbs.

Mohamed, (2004), stated that Balady cultivar showed higher percentage of loss during the various periods of storage compared with Sids-40. Also, Ammar (2007) found that Sids-40 cultivar gave the lowest value of weight loss percentage compared to Balady cultivar after one month of storage ,but ,after seven months of storage Balady cultivar gave lower weight loss percentage than Sids-40 cultivar .

One the other hand, Dawood et al (2011) found that weight loss percentage was lower in the bulbs of Balady cultivar, followed by Sids- 40 cultivar .

This study was suggested to investigate the effects of planting dates, on vegetative growth characters, yield and its components of two garlic cultivars; Balady and Sids-40 as well as to follow up the effects of those pre-harvest treatments and periods 
of curing 14 and 21 days on the storability of garlic bulbs under different storage periods.

\section{MATERIALS AND METHODS}

Two field experiments were carried out during the winter seasons of 2013/2014 and 2014/2015. The experiments were conducted at the Agricultural Experimental Station Farm (at Abies) Faculty of Agriculture, Alexandria university, to investigate the effect of planting dates $\left(10^{\text {th }}\right.$ of September, $1^{\text {st }}$ of October and $20^{\text {th }}$ of October) on vegetative growth characters, , yield and its components and quality characteristics of two garlic cultivars (Balady and Sids-40).The experimental layout was a split- plot system in a randomized complete blocks design with three replications .Main plots consisted of planting dates ; sub-plots were allocated to the cultivars.

Garlic cultivars: Two garlic cultivars were used in this study ,e.g., Balady and Sids-40, the most common commercial garlic cultivars in Egyptian fresh market. Balady is a local garlic cv. popularly grown in Egypt for their strong smell owing to its natural properties, whose mature cloves have white covering scale with relatively long storability. While, Sids- 40 is well-known by its big cloves size, easy peer, whose mature cloves have bright white skin with purple vertical stripes.

Uniform and healthy cloves (each $1.0 \mathrm{~g} \pm 0.1$ /clove) of the two garlic cultivars were planted upright with apical tip on both sides of row at in-row spacing $10 \mathrm{~cm}$. Each sub-plot contained eight rows of $4 \mathrm{~m}$ length and $0.60 \mathrm{~m}$ width occupying an area of 19.2 square meters. All experimental units received identical doses of nitrogen, phosphorus and potassium at rates of 120, 75 and $48 \mathrm{~kg}$ fed-1, orderly. Ammonium sulphate $(20.5 \% \mathrm{~N})$, Calcium super phosphate (15.5\% P2O5) and potassium sulphate (48\% K2O) were the respective forms of fertilizers. Nitrogen fertilizer was banded at three applications; 3, 7 and 10 weeks after sown. Phosphorus fertilizer was broadcasted during soil preparation. Potassium fertilizer was banded at one application at 10 weeks after sown. After sowing directly and before irrigation, weeds were controlled by using pre-emergence of Stomp herbicide. After 21days from planting, weeds were controlled by using post-emergence of Joel herbicide. . A guard raw was left between each sub-plot as a separator. All other agricultural practices were performed when they were required and as recommended for the commercial garlic production. When older leaves turned yellowish green and had started withering, plants of each plot were harvested. 


\section{Data Recorded.}

Vegetative growth characters: A random sample of ten plants of each cultivar, was collected from each plot after 150 days from planting to estimate the following parameters ; plant height (cm) , number of leaves /plant and shoot dry weight/plant..

Bulb yield and its components: At harvest time, marketable bulbs of both garlic cultivars from each plot were weighed to estimate total fresh yield (Ton/fed). A random sample of 10 head bulbs derived from each cultivar were taken from each sub -plot to determine head bulb weight, head bulb diameter, neck diameter as well as the number of cloves /head bulb, external clove weight and endow clove weight and bulbing ratio, according to the following equation:

diameter(cm)

$$
\text { Bulbing ratio }=\text { neck diameter }(\mathrm{cm}) / \text { bulb }
$$

Post-harvest Experiments: Two post-harvest experiments were executed at the Post-harvest laboratory of Sabahi Station, Agricultural Research Center, Alexandria during the two seasons of 2014 and 2015. The objective of these experiments was to follow up the effects of pre-harvest treatments (dates of planting and two cultivars) and post-harvest treatments (curing14 days and 21 days) on storability of garlic cultivars. Garlic plants were cured with leaves where the bulb continues to draw energy from the leaves and roots until all that moisture evaporates. After cured, cut the stalks down to an inch above the bulbs, and trim the roots and store the cured heads in net bags.

The garlic was placed on an elevated wire screen or slotted tray to promote drying and stored at the normal room conditions $(20+2$ C, $60-65 \%$ relative humidity). Data were monthly recorded during the storage period (6 months). Weight loss percentage and some chemical constituents of stored roots were recorded. The experimental layout was a split-spilt plot system in a randomized complete blocks design with three replications. Main plots consisted of planting dates, sub-plots were cultivars and sub -sup plot were allocated to the curing 14 and21 days, which were subjected to different periods of storage at room temperature, i.e.; 30, 60, 90, 120, 150 and 180 days.

Statistical analysis: Data obtained were subjected to statistical analyses using Co-State Software (2004). For treatments that were significant, mean separation was done using the Revised Least Significantly Difference (LSD) test, at 0.05 probability level (Steel and Torrio, 1980). 


\section{RESULTS AND DISCUSSION \\ Vegetative growth characters:}

Significant differences among the plant morphological characters due to planting dates were detected Table (1). Planting garlic cloves at early planting date $\left(10^{\text {th }}\right.$ September $)$ significantly increased plant height, number of leaves and plant fresh weight, compared with those plants which were planted at late planting date $\left(20^{\text {th }}\right.$ October), in both seasons. The lowest mean values of vegetative growth characters were recorded with late planting date $\left(20^{\text {th }}\right.$ October). The pronounced positive effects of early planting on vegetative growth characters of Balady and Sids- 40 cultivars might be due to that the plants received cool weather period and a shorter day length which enhanced the vegetative growth before the formation of bulbs. Similar findings were also obtained by El-Zohiri and Farag (2014), Youssef and Tony (2014), reported that early planting dates exhibited higher vegetative growth of garlic plants.

Differences between Cultivars were detected concerning vegetative growth Table(1). In this respect, Balady cultivar recorded higher mean values of plant height, however, Sids-40 exhibited higher values for number of leaves and plant fresh weight, in both seasons. These results might be expected due to based on the genetic structure that characterized each garlic cultivar and the differences between their genotypes. The obtained results are in harmony with those reported by Abdel -Razzak and El-Sharkawy (2013), Zaki et al. (2014).

Concerning the interaction effect between planting dates and cultivars on vegetative growth characters showed that the Balady cultivar seemed to have taller plants than Sids-40 on either the various planting dates. However, Sids- 40 recorded the highest mean values for number of leaves and plant fresh weight at the different planting dates, in both seasons. 
Table (1): Plant height $(\mathrm{cm})$, number of leaves plant ${ }^{-1}$ and plant fresh weight (g) of garlic plants as affected by planting dates of the two tested cultivars and their interaction during the winter seasons of 2013-2014 and 2014-2015

\begin{tabular}{|c|c|c|c|c|c|c|c|}
\hline \multirow{2}{*}{\multicolumn{2}{|c|}{ Treatments }} & \multicolumn{2}{|c|}{ Plant height $(\mathrm{cm})$} & \multicolumn{2}{|c|}{ Number of leaves plant- } & \multicolumn{2}{|c|}{ Plant fresh weight (g) } \\
\hline & & \multirow[t]{2}{*}{$\begin{array}{c}2013- \\
2014 \\
\end{array}$} & \multirow[t]{2}{*}{$2014-2015$} & \multirow[t]{2}{*}{$2013-2014$} & \multirow[t]{2}{*}{$2014-2015$} & \multirow[t]{2}{*}{$2013-2014$} & \multirow[t]{2}{*}{$2014-2015$} \\
\hline $\begin{array}{c}\text { Planting } \\
\text { dates }\end{array}$ & & & & & & & \\
\hline $10^{\text {th }}$ Sep & & $69.08 \mathrm{a}$ & $66.88 \mathrm{a}$ & 10.84 a & $9.52 \mathrm{a}$ & 125.98 a & $127.13 \mathrm{a}$ \\
\hline $1^{\text {st }}$ Oct & & $64.56 a$ & $64.03 \mathrm{~b}$ & $10.94 \mathrm{a}$ & $9.17 \mathrm{a}$ & $112.88 \mathrm{~b}$ & $122.16 \mathrm{~b}$ \\
\hline \multirow[t]{4}{*}{$20^{\text {th }}$ Oct } & & $59.51 \mathrm{~b}$ & $57.52 \mathrm{c}$ & $9.47 \mathrm{~b}$ & $7.67 \mathrm{~b}$ & $89.20 \mathrm{c}$ & $88.16 \mathrm{c}$ \\
\hline & cultivars & & & & & & \\
\hline & Sids-40 & $51.92 \mathrm{~b}$ & $58.76 \mathrm{~b}$ & $10.88 \mathrm{a}$ & $9.69 \mathrm{a}$ & $115 . .49 \mathrm{a}$ & 115.97 a \\
\hline & Balady & $76.83 \mathrm{a}$ & $67.89 \mathrm{a}$ & $9.95 \mathrm{~b}$ & $7.88 \mathrm{~b}$ & $109.21 \mathrm{~b}$ & $108.99 \mathrm{~b}$ \\
\hline \multicolumn{8}{|c|}{$\begin{array}{l}\text { Planting dates } \\
\text { cultivars }\end{array}$} \\
\hline \multirow[t]{2}{*}{$10^{\text {th }}$ Sep } & Sids-40 & $59.33 \mathrm{~b}$ & $59.66 \mathrm{~b}$ & 11.58 a & $11.04 \mathrm{a}$ & $131.25 \mathrm{a}$ & $123.57 \mathrm{a}$ \\
\hline & Balady & $78.83 \mathrm{a}$ & $74.11 \mathrm{a}$ & $10.11 \mathrm{~b}$ & $08.00 \mathrm{c}$ & $120.71 \mathrm{~b}$ & $130.70 \mathrm{a}$ \\
\hline \multirow{2}{*}{$1^{\text {st }}$ Oct } & Sids-40 & $50.78 \mathrm{c}$ & $57.07 \mathrm{~b}$ & $11.55 \mathrm{a}$ & $09.67 \mathrm{~b}$ & $114.41 \mathrm{~b}$ & $122.92 \mathrm{a}$ \\
\hline & Balady & $78.33 \mathrm{a}$ & $70.99 \mathrm{a}$ & $10.32 \mathrm{~b}$ & $08.66 \mathrm{c}$ & $111.36 \mathrm{~b}$ & $121.41 \mathrm{a}$ \\
\hline \multirow{2}{*}{$20^{\text {th }}$ Oct } & Sids-40 & $45.68 \mathrm{c}$ & $56.22 \mathrm{~b}$ & $9.53 \mathrm{c}$ & $08.33 \mathrm{c}$ & $100.83 \mathrm{c}$ & $101.43 \mathrm{~b}$ \\
\hline & Balady & $73.33 \mathrm{a}$ & $58.83 \mathrm{~b}$ & $9.41 \mathrm{c}$ & $07.00 \mathrm{~d}$ & $95.56 \mathrm{c}$ & $74.88 \mathrm{c}$ \\
\hline
\end{tabular}

* Values having the same alphabetical letter (s) in common, within a particular group of means in each character, do not significantly differ, using the revised L.S.D. test at 0.05 level.

\section{Bulb yield and its components:}

Data in Table (2), clearly indicated that planting dates had a significant effect on bulb yield and its components, in both seasons. Early planting (on $10^{\text {th }}$ of Sep). resulted in higher values of bulb weight , bulb diameter, neck diameter and bulbing ratio for Balady and Sids40 cultivars over than those of late planting $\left(20^{\text {th }}\right.$ October), in both seasons. The enhancement of bulb yield and its components as a results of early planting might be due to that the plants received enough earlier cool weather period and a shorter day length which enhanced the vegetative growth of plant before the formation of their bulbs, consequently, resulting in assimilation of more carbohydrates and their translocation to the bulbs, leading to increase head bulb yield and its components. This result is in harmony with finding of Swati Barch et al. (2013), El-Zohari and Farag (2014) and Youssef and Tony (2014).

Data in Tables (2 and 3), indicated that Sids-40 cultivar gave heavier bulbs, and thicker bulb diameter as compared to Balady cultivar. However, Balady cultivar exhibited higher mean values for number of cloves head ${ }^{-1}$, neck diameter and bulbing ratio. These results might be referred to the genetic variation among garlic cultivars and their abilities to benefit from the environmental sources, particularly, light , $\mathrm{CO}_{2}$, water and nutrients. The obtained results are in harmony with those reported by Wafaa.Fekry (2011), Abed-Alrazza and El-Sharkawey (2013) and Zaki et al. (2014). 
Table (2): Bulb weight $(\mathrm{g})$, bulb diameter $(\mathrm{cm})$, neck diameter $(\mathrm{cm})$ and bulbing ratio of garlic plants, as affected by planting dates for the two tested cultivars and their interaction during the winter seasons of 2013-2014 and 2014-2015

\begin{tabular}{|c|c|c|c|c|c|c|c|c|c|}
\hline \multirow{2}{*}{\multicolumn{2}{|c|}{ Treatments }} & \multicolumn{2}{|c|}{ Bulb weight (g) } & \multicolumn{2}{|c|}{ Bulb diameter(cm) } & \multicolumn{2}{|c|}{ Neck diameter(cm) } & \multicolumn{2}{|c|}{ Bulbing ratio } \\
\hline & & $2013-2014$ & $\begin{array}{l}2014- \\
2015\end{array}$ & $\begin{array}{l}2013- \\
2014\end{array}$ & $2014-2015$ & $\begin{array}{l}2013- \\
2014\end{array}$ & $\begin{array}{l}2014- \\
2015\end{array}$ & $\begin{array}{l}2013- \\
2014\end{array}$ & $\begin{array}{l}2014- \\
2015\end{array}$ \\
\hline \multicolumn{10}{|c|}{ Planting dates } \\
\hline $10^{\text {th }}$ Sep & & $79.30 \mathrm{a}$ & $77.27 \mathrm{a}$ & $6.35 \mathrm{a}$ & $6.14 \mathrm{a}$ & $1.26 \mathrm{a}$ & $1.46 \mathrm{a}$ & $0.20 \mathrm{a}$ & $0.26 \mathrm{a}$ \\
\hline $1^{\text {st }}$ Oct & & $58.49 \mathrm{~b}$ & $74.77 \mathrm{a}$ & $5.08 \mathrm{~b}$ & $5.39 \mathrm{~b}$ & $1.00 \mathrm{~b}$ & $1.42 \mathrm{a}$ & $0.20 \mathrm{a}$ & $0.28 \mathrm{a}$ \\
\hline \multirow[t]{4}{*}{$20^{\text {nn }}$ Oct } & & $45.74 \mathrm{c}$ & $60.96 \mathrm{~b}$ & $4.31 \mathrm{c}$ & $4.71 \mathrm{c}$ & $0.90 \mathrm{~b}$ & $1.05 \mathrm{~b}$ & $0.21 \mathrm{a}$ & $0.22 \mathrm{a}$ \\
\hline & Cultivars & & & & & & & & \\
\hline & Sids-40 & $62.91 \mathrm{a}$ & $77.52 \mathrm{a}$ & $5.61 \mathrm{a}$ & $6.21 \mathrm{a}$ & $0.93 \mathrm{~b}$ & $1.16 \mathrm{~b}$ & $0.17 \mathrm{~b}$ & $0.19 \mathrm{~b}$ \\
\hline & Balady & $59.45 \mathrm{~b}$ & $64.31 \mathrm{~b}$ & $4.87 \mathrm{~b}$ & $4.62 \mathrm{~b}$ & $1.17 \mathrm{a}$ & $1.46 \mathrm{a}$ & $0.24 \mathrm{a}$ & $0.31 \mathrm{a}$ \\
\hline \multicolumn{10}{|c|}{$\begin{array}{l}\text { Planting dates } \\
\text { Cultivars }\end{array}$} \\
\hline \multirow{2}{*}{$10^{\text {th }}$ Sep } & Sids-40 & $90.85 \mathrm{a}$ & $83.15 \mathrm{a}$ & $7.05 \mathrm{a}$ & $7.21 \mathrm{a}$ & $1.13 \mathrm{~b}$ & $1.1 \mathrm{a}$ & $0.16 \mathrm{c}$ & $0.16 \mathrm{c}$ \\
\hline & Balady & $67.75 \mathrm{~b}$ & 74.74 abc & $5.66 \mathrm{~b}$ & $5.06 \mathrm{c}$ & $1.80 \mathrm{a}$ & $1.30 a$ & $0.25 \mathrm{a}$ & $0.36 \mathrm{a}$ \\
\hline \multirow{2}{*}{$1^{\text {st }}$ Oct } & Sids-40 & $54.62 \mathrm{~d}$ & $79.81 a b$ & $5.18 \mathrm{c}$ & $6.28 \mathrm{~b}$ & $1.16 \mathrm{~b}$ & $1.23 \mathrm{a}$ & $0.15 \mathrm{c}$ & $0.18 \mathrm{bc}$ \\
\hline & Balady & $62.36 \mathrm{c}$ & $66.39 \mathrm{c}$ & $4.96 \mathrm{c}$ & $4.50 \mathrm{~d}$ & $1.67 \mathrm{a}$ & $1.10 \mathrm{a}$ & $0.25 \mathrm{a}$ & $0.37 a$ \\
\hline \multirow{2}{*}{$20^{\text {th }}$ Oct } & Sids-40 & $43.52 \mathrm{f}$ & $69.61 \mathrm{bc}$ & $4.61 \mathrm{~d}$ & $5.13 \mathrm{c}$ & $1.20 \mathrm{~b}$ & $1.20 \mathrm{a}$ & $0.19 \mathrm{bc}$ & $0.23 \mathrm{~b}$ \\
\hline & Balady & $48.23 \mathrm{e}$ & $51.78 \mathrm{~d}$ & $4.00 \mathrm{e}$ & $4.30 \mathrm{~d}$ & $0.90 \mathrm{~b}$ & $0.73 \mathrm{~b}$ & $0.23 \mathrm{ab}$ & $0.21 \mathrm{bc}$ \\
\hline
\end{tabular}

* Values having the same alphabetical letter (s) in common, within a particular group of means in each character, do not significantly differ, using the revised L.S.D. test at 0.05 level

Data presented in Tables (4 and 5), revealed that the average total fresh yield (Ton fed ${ }^{-1}$ ) significantly influenced by planting dates. Early planting $\left(10^{\text {th }}\right.$ September and $1^{\text {st }}$ October $)$, significantly, resulted in higher total fresh yield as compared to late planting. Delaying planting until $20^{\text {th }}$ October, however, led to reduction of fresh yield per fed as compared to the $10^{\text {th }}$ of September. These yield increments, due to early planting might be related to the suitable environment including longer cool growing period and shorter day, which is essential for proper vegetative growth as well as bulb formation and development of garlic plants. These results are consistent with those documented by El-Zohiri and Farag (2014) and Youssef and Tony (2014), who indicated yield reduction due to delaying of planting date of garlic plants.

The data also revealed that Sids-40 cultivar was significantly better than Balady cultivar in terms of fresh bulb yield, total yield cured 14 days, total yield cured 21 days, total bulb yield cured14 and total bulb yield cured 21 days in two seasons. The obtained results are in harmony with those reported by Zaki et al. (2014). 
Table (3): Endow clove weight, External clove weight and number of cloves per bulb of garlic plants, as affected by planting dates for the two tested cultivars and their interaction during the winter seasons of 2013-2014 and2014-2015

\begin{tabular}{|c|c|c|c|c|c|c|c|}
\hline \multirow{2}{*}{\multicolumn{2}{|c|}{ Treatments }} & \multicolumn{2}{|c|}{ Endow clove weight(g) } & \multicolumn{2}{|c|}{ External clove weight(g) } & \multicolumn{2}{|c|}{ Number of cloves bulb ${ }^{-1}$} \\
\hline & & \multirow{2}{*}{$2013-2014$} & \multirow[t]{2}{*}{$2014-2015$} & \multirow[t]{2}{*}{$2013-2014$} & \multirow[t]{2}{*}{$2014-2015$} & \multirow[t]{2}{*}{$2013-2014$} & \multirow[t]{2}{*}{$2014-2015$} \\
\hline Planting dates & & & & & & & \\
\hline $10^{\text {mn Sep }}$ & & $3.055 \mathrm{a}$ & $2.92 \mathrm{a}$ & $4.73 \mathrm{a}$ & $5.01 \mathrm{a}$ & $22.37 \mathrm{a}$ & $26.50 \mathrm{a}$ \\
\hline $1^{\text {st }}$ Oct & & $2.698 \mathrm{a}$ & $2.30 \mathrm{a}$ & $4.79 \mathrm{a}$ & $4.21 \mathrm{~b}$ & $22.72 \mathrm{a}$ & $25.66 \mathrm{a}$ \\
\hline \multirow[t]{4}{*}{$20^{\text {mn }}$ Oct } & & $2.156 \mathrm{~b}$ & $2.06 \mathrm{a}$ & $4.00 \mathrm{a}$ & $3.72 \mathrm{~b}$ & $21.81 \mathrm{a}$ & $21.33 \mathrm{~b}$ \\
\hline & Cultivars & & & & & & \\
\hline & Sids40 & $4.801 \mathrm{a}$ & $4.46 \mathrm{a}$ & $6.63 \mathrm{a}$ & $6.46 \mathrm{a}$ & $10.50 \mathrm{~b}$ & $12.11 \mathrm{~b}$ \\
\hline & Balady & $0.472 \mathrm{~b}$ & $0.40 \mathrm{~b}$ & $2.28 \mathrm{~b}$ & $2.16 \mathrm{~b}$ & $34.10 \mathrm{a}$ & $36.88 \mathrm{a}$ \\
\hline \multicolumn{8}{|c|}{ Planting dates 13} \\
\hline \multirow{2}{*}{$10^{\text {th }}$ Sep } & Sids-40 & $5.49 \mathrm{a}$ & $5.35 \mathrm{a}$ & $7.06 \mathrm{a}$ & $7.71 \mathrm{a}$ & $11.78 \mathrm{c}$ & $14.00 \mathrm{c}$ \\
\hline & Balady & $0.61 \mathrm{~b}$ & $0.50 \mathrm{~b}$ & $2.41 \mathrm{~b}$ & $2.29 \mathrm{~d}$ & $32.96 \mathrm{~b}$ & $39.00 \mathrm{a}$ \\
\hline \multirow{2}{*}{$1^{\text {st }}$ Oct } & Sids-40 & $4.97 \mathrm{a}$ & $3.80 \mathrm{a}$ & $7.18 \mathrm{a}$ & $6.29 \mathrm{~b}$ & $10.11 \mathrm{~cd}$ & $13.00 \mathrm{c}$ \\
\hline & Balady & $0.43 \mathrm{~b}$ & $0.33 \mathrm{~b}$ & $2.39 \mathrm{~b}$ & $2.13 \mathrm{~d}$ & $35.33 \mathrm{a}$ & $38.33 \mathrm{a}$ \\
\hline \multirow{2}{*}{$20^{\text {th }} \mathrm{Oct}$} & Sids-40 & $3.93 \mathrm{a}$ & $4.24 \mathrm{a}$ & $5.66 \mathrm{a}$ & $5.39 \mathrm{c}$ & $9.62 \mathrm{~d}$ & $9.33 \mathrm{~d}$ \\
\hline & Balady & $0.37 \mathrm{~b}$ & $0.36 \mathrm{~b}$ & $2.34 \mathrm{~b}$ & $2.04 \mathrm{~d}$ & $34.00 \mathrm{ab}$ & $33.33 \mathrm{~b}$ \\
\hline
\end{tabular}

* Values having the same alphabetical letter (s) in common, within a particular group of means in each character, do not significantly differ, using the revised L.S.D. test at 0.05 level.

Table (4): Total fresh yield(bulbs with leaves) ,total yield(bulbs with leaves) cured 14 days and total yield (bulbs with leaves) cured 21 days of garlic plants as affected by planting, dates for the two tested cultivars and their interaction during the winter seasons of 2013-2014 and20142015

\begin{tabular}{|c|c|c|c|c|c|c|c|}
\hline \multirow{2}{*}{\multicolumn{2}{|c|}{ Treatments }} & \multicolumn{2}{|c|}{$\begin{array}{l}\text { Total fresh yield (t/fed) } \\
\text { (bulbs with leaves) }\end{array}$} & \multicolumn{2}{|c|}{$\begin{array}{l}\text { Total yield (bulbs with leaves) } \\
\text { cured } 14 \text { days }\end{array}$} & \multicolumn{2}{|c|}{$\begin{array}{l}\text { Total yield (bulbs with leaves) cured } \\
\text { 21days }\end{array}$} \\
\hline & & $2013-2014$ & $2014-2015$ & $2013-2014$ & $2014-2015$ & $2013-2014$ & $2014-2015$ \\
\hline \multicolumn{8}{|l|}{$\begin{array}{l}\text { Planting } \\
\text { dates }\end{array}$} \\
\hline $10^{\text {ln }}$ Sep & & $14.398 \mathrm{a}$ & $12.974 \mathrm{a}$ & $8.226 a$ & $8.523 \mathrm{a}$ & $7.948 a$ & $8.204 \mathrm{a}$ \\
\hline $1^{\text {st }}$ Oct & & $13.782 b$ & $12.466 \mathrm{~b}$ & $8.202 \mathrm{a}$ & $8.079 \mathrm{a}$ & $7.753 \mathrm{a}$ & $7.579 \mathrm{~b}$ \\
\hline \multirow[t]{4}{*}{$20^{\text {ln }}$ Oct } & & $10.552 \mathrm{c}$ & $10.588 \mathrm{c}$ & $6.677 \mathrm{~b}$ & $6.337 \mathrm{~b}$ & $5.901 \mathrm{~b}$ & $5.975 \mathrm{c}$ \\
\hline & Cultivars & & & & & & \\
\hline & Sids -40 & $13.488 \mathrm{a}$ & $12.709 \mathrm{a}$ & $8.669 a$ & $8.919 a$ & $8.346 \mathrm{a}$ & $8.306 \mathrm{a}$ \\
\hline & Balady & $12.333 \mathrm{~b}$ & $11.309 \mathrm{~b}$ & $6.735 \mathrm{~b}$ & $6.387 \mathrm{~b}$ & $6.055 \mathrm{~b}$ & $6.199 \mathrm{~b}$ \\
\hline \multicolumn{8}{|l|}{ Plant dates } \\
\hline \multirow[t]{2}{*}{$10^{\text {th }}$ Sep } & Sids40 & 14.967 a & $13.785 \mathrm{a}$ & $9.690 \mathrm{a}$ & $9.433 \mathrm{a}$ & $8.986 \mathrm{a}$ & $9.100 \mathrm{a}$ \\
\hline & Balady & $13.829 \mathrm{~b}$ & $12.162 \mathrm{c}$ & $7.158 \mathrm{~b}$ & $7.614 \mathrm{~b}$ & $6.913 \mathrm{~b}$ & $7.309 \mathrm{~b}$ \\
\hline \multirow{2}{*}{$1^{\text {st }}$ Oct } & Sids40 & $14.680 \mathrm{a}$ & $13.224 \mathrm{~b}$ & $9.674 \mathrm{a}$ & $9.443 \mathrm{a}$ & $9.301 \mathrm{a}$ & $8.871 \mathrm{a}$ \\
\hline & Balady & $12.885 \mathrm{c}$ & $11.709 \mathrm{~d}$ & $7.050 \mathrm{~b}$ & $6.752 \mathrm{~b}$ & $6.205 \mathrm{c}$ & $6.286 \mathrm{c}$ \\
\hline \multirow{2}{*}{$20^{\text {th }}$ Oct } & Sids 40 & $10.819 \mathrm{~d}$ & $11.118 \mathrm{c}$ & $7.222 \mathrm{~b}$ & $7.880 \mathrm{~b}$ & $6.755 \mathrm{bc}$ & $6.947 \mathrm{~b}$ \\
\hline & Balady & $10.286 \mathrm{~d}$ & $10.057 f$ & $6.124 \mathrm{c}$ & $4.794 \mathrm{c}$ & $5.047 \mathrm{~d}$ & $5.007 \mathrm{~d}$ \\
\hline
\end{tabular}

* Values having the same alphabetical letter (s) in common, within a particular group of means in each character, do not significantly differ, using the revised L.S.D. test at 0.05 level. 
Table (5) Total bulbs (without leaves) yield cured 14 days and total bulb yield(without leaves) cured 21 days of garlic plants as affected by planting dates for the two tested cultivars and their interaction during the winter seasons of 2013-2014 and2014-2015

\begin{tabular}{|c|c|c|c|c|c|}
\hline \multicolumn{2}{|c|}{ Treatments } & \multicolumn{2}{|c|}{ Total bulb yield cured14 day (t/fed) } & \multicolumn{2}{|c|}{ Total bulb yield cured21 day (t/fed) } \\
\hline & & $2013-2014$ & $2014-2015$ & $2013-2014$ & $2014-2015$ \\
\hline \multicolumn{6}{|l|}{ Plant dates } \\
\hline $10^{\text {th }}$ Sep & & $6.887 \mathrm{a}$ & $7.338 \mathrm{a}$ & $6.676 \mathrm{a}$ & $7.016 \mathrm{a}$ \\
\hline $1^{\text {st }}$ Oct & & $7.061 \mathrm{a}$ & $6.494 \mathrm{~b}$ & $6.686 \mathrm{a}$ & $6.131 \mathrm{~b}$ \\
\hline \multirow[t]{4}{*}{$20^{\text {ln }}$ Oct } & & $5.477 \mathrm{~b}$ & $5.239 \mathrm{c}$ & $5.217 \mathrm{~b}$ & $4.828 \mathrm{c}$ \\
\hline & Cultivars & & & & \\
\hline & Sids40 & $7.551 \mathrm{a}$ & $7.204 \mathrm{a}$ & $7.402 \mathrm{a}$ & $6.758 \mathrm{a}$ \\
\hline & Balady & $5.400 \mathrm{~b}$ & $5.510 \mathrm{~b}$ & $5.117 \mathrm{~b}$ & $5.231 \mathrm{~b}$ \\
\hline \multicolumn{6}{|l|}{ Planting dates } \\
\hline \multirow[t]{2}{*}{$10^{\text {lh }}$ Sep } & Sids40 & $7.987 \mathrm{a}$ & $8.055 a$ & $7.728 \mathrm{~b}$ & $7.761 \mathrm{a}$ \\
\hline & Balady & $5.787 \mathrm{bc}$ & $6.621 \mathrm{~b}$ & $5.624 \mathrm{~cd}$ & $6.271 \mathrm{c}$ \\
\hline \multirow{2}{*}{$1^{\text {st }}$ Oct } & Sids40 & $8.45 \mathrm{a}$ & 7.576 & $8.412 \mathrm{a}$ & $6.946 \mathrm{~b}$ \\
\hline & Balady & $5.672 \mathrm{bc}$ & $5.414 \mathrm{C}$ & $5.36 \mathrm{~cd}$ & $5.316 \mathrm{~d}$ \\
\hline \multirow{2}{*}{$20^{\text {th }}$ Oct } & Sids40 & $6.212 \mathrm{~b}$ & $5.982 \mathrm{bc}$ & $6.067 \mathrm{c}$ & $5.550 \mathrm{a}$ \\
\hline & Balady & $4.740 \mathrm{c}$ & $4.498 \mathrm{~d}$ & $4.367 \mathrm{e}$ & $4.106 \mathrm{e}$ \\
\hline
\end{tabular}

* Values having the same alphabetical letter (s) in common, within a particular group of means in each character, do not significantly differ, using the revised L.S.D. test at 0.05 level.

\section{Weight loss percentage as affected by planting dates, cultivars and period of curing during storage periods in two seasons:}

Data presented in Table (6) displayed that the garlic plants of the two cultivars gained from early planting $\left(10^{\text {th }}\right.$ of Sept $)$, gave the highest weight loss during curing process irrespective the period ( 14 and 21 days), compared to intermediate or late planting (1st and 20th of Oct.), in both seasons .Results, also, indicated that Balady cultivar exhibited higher weight loss during curing than Sids-40 one, under all circumstances i. e, either period of storage or date of planting. The obtained results are in harmony with those reported by Ammar (2007). Dawood et al. (2011) and Hassan (2015). In addition , curing for 21 days resulted in higher weight loss percentage than those of curing for 14 days. Similar findings were also obtained by. Yang and Lee (2000). Jauron and Wallace (2014):

Weight loss \% in garlic bulbs during storage, as affected by planting dates, cultivars and period of curing 2014 and 2015.

Data presented in Tables (7 and 8), showed that storage for 30 days resulted in the lowest weight loss percentage which, in the mean time, it is the maximally accepted value economically, and quality period of view, in both seasons. Moreover, the obtained results reflected that planting garlic in early dates gave the highest weight loss, in both seasons. Prolonging the period of storage caused gradual increase in weight loss percentage according to the planting dates, cultivar, and period of curing. 
Table (6): Weight loss percentage, as affected by planting dates, cultivars during periods of curing in two seasons

\begin{tabular}{|c|c|c|c|c|c|c|}
\hline \multicolumn{3}{|c|}{ Treatments } & $\begin{array}{l}\text { Weight loss } \\
\text { in garlic } \\
\text { bulbs with } \\
\text { leaves }\end{array}$ & $\begin{array}{l}\text { Weight loss } \\
\text { in garlic } \\
\text { bulbs } \\
\text { without }\end{array}$ & $\begin{array}{l}\text { Weight loss } \\
\text { in garlic } \\
\text { bulbs with } \\
\text { leaves }\end{array}$ & $\begin{array}{l}\text { Weight loss in } \\
\text { garlic bulbs } \\
\text { without leaves }\end{array}$ \\
\hline $\begin{array}{c}\text { Planting } \\
\text { dates }\end{array}$ & & & \multicolumn{2}{|c|}{2014} & \multicolumn{2}{|c|}{2015} \\
\hline $10^{\text {In }}$ Sep & & & $44.08 \mathrm{a}$ & $53.13 \mathrm{a}$ & $42.06 \mathrm{a}$ & $54.10 \mathrm{a}$ \\
\hline $1^{\text {st }}$ Oct & & & $42.59 \mathrm{ab}$ & $49.90 \mathrm{~b}$ & $37.65 \mathrm{~b}$ & $49.53 \mathrm{a}$ \\
\hline \multirow[t]{7}{*}{$20^{\text {th }}$ Oct } & & & $40.66 \mathrm{~b}$ & $49.51 \mathrm{~b}$ & $36.04 \mathrm{~b}$ & $44.87 \mathrm{~b}$ \\
\hline & Cultivars & & & & & \\
\hline & Sids -40 & & $36.81 \mathrm{~b}$ & $44.41 \mathrm{~b}$ & $33.71 \mathrm{~b}$ & $46.22 \mathrm{~b}$ \\
\hline & Balady & & $48.09 \mathrm{a}$ & $57.28 \mathrm{a}$ & $43.45 \mathrm{a}$ & $52.78 \mathrm{a}$ \\
\hline & & $\begin{array}{c}\text { Curing } \\
\text { periods }\end{array}$ & & & & \\
\hline & & $\begin{array}{c}14 \\
\text { days }\end{array}$ & $40.33 \mathrm{~b}$ & 49.98 a & $36.15 \mathrm{~b}$ & $48.31 \mathrm{~b}$ \\
\hline & & $\begin{array}{c}21 \\
\text { days }\end{array}$ & $44.56 \mathrm{a}$ & $51.71 \mathrm{a}$ & $41.01 \mathrm{a}$ & 50.69 a \\
\hline
\end{tabular}

*Values having the same alphabetical letter (s) in common, within a particular group of means in each character, do not significantly differ, using the revised L.S.D. test at 0.05 level.

Generally Sids-40 cultivar yielded higher weight loss percentage than Balady cultivar under all circumstances, i.e. either period of storage or date of planting. The obtained results are in harmony with those reported by Ammar (2007) Dawood et al. (2011) Curing garlic for 21 days before storage resulted in better results, in lens of weight loss than of curing for 14 days in both seasons Tables ( 6 and 7), Similar findings were also obtained by Yang and Lee (2000).and Jauron and Wallace (2014):

Table (7): Weight loss \% in garlic bulbs during storage, as affected by planting dates, cultivars and period of curing during season 2014

\begin{tabular}{|c|c|c|c|c|c|c|c|c|}
\hline \multirow{2}{*}{\multicolumn{3}{|c|}{$\begin{array}{c}\text { Treatments } \\
\text { Storage periods }\end{array}$}} & \multicolumn{6}{|c|}{ Weight loss \% in garlic bulbs during storage periods in 2014} \\
\hline & \multicolumn{2}{|c|}{ Storage periods } & 30 Days & 60 Days & 90 Days & 120 Days & 150 Days & 180 Days \\
\hline \multicolumn{9}{|c|}{\begin{tabular}{l|l} 
Planting \\
dates
\end{tabular}} \\
\hline $10^{\text {th }}$ Sep & & & $14.42 \mathrm{a}$ & $19.73 \mathrm{a}$ & 23.58 a & 28.11 a & 30.95 a & $34.35 \mathrm{a}$ \\
\hline $1^{\text {st }}$ Oct & & & $12.77 \mathrm{~b}$ & $15.10 \mathrm{~b}$ & $19.68 \mathrm{~b}$ & $21.94 \mathrm{~b}$ & 26.78 a & $28.96 \mathrm{~b}$ \\
\hline \multirow[t]{5}{*}{$20^{\text {th }}$ Oct } & & & $11.93 \mathrm{~b}$ & $13.59 \mathrm{~b}$ & $15.03 \mathrm{c}$ & $18.81 \mathrm{~b}$ & $21.31 \mathrm{~b}$ & $27.37 \mathrm{~b}$ \\
\hline & cultivars & & & & & & & \\
\hline & Sids40 & & $14.30 \mathrm{a}$ & $17.22 \mathrm{a}$ & 20.93 a & 25.79 a & 29.11 a & $33.42 \mathrm{a}$ \\
\hline & Balady & & $11.79 \mathrm{~b}$ & $15.06 \mathrm{~b}$ & $17.94 \mathrm{~b}$ & $20.12 \mathrm{~b}$ & $23.58 \mathrm{~b}$ & 27.04 b \\
\hline & & $\begin{array}{l}\text { Curing } \\
\text { periods }\end{array}$ & & & & & & \\
\hline & & 14 days & 15.40 a & $19.17 \mathrm{a}$ & 22.53 a & $26.51 \mathrm{a}$ & 29.04 a & $33.52 \mathrm{a}$ \\
\hline & & 21 days & $10.68 \mathrm{~b}$ & $13.11 \mathrm{~b}$ & $16.34 \mathrm{~b}$ & $19.40 \mathrm{~b}$ & $23.65 \mathrm{~b}$ & $26.94 \mathrm{~b}$ \\
\hline
\end{tabular}

* Values having the same alphabetical letter (s) in common, within a particular group of means in each character, do not significantly differ, using the revised L.S.D. test at 0.05 level 
Table (8): Weight loss \% in garlic bulbs during storage, as affected by planting dates, cultivars and period of curing during season 2015

\begin{tabular}{|c|c|c|c|c|c|c|c|c|}
\hline \multicolumn{3}{|c|}{ Treatments } & \multicolumn{6}{|c|}{ Weight loss percentage during storage periods in 2015} \\
\hline \multicolumn{3}{|c|}{ Storage periods } & 30 Days & 60 Days & 90 Days & 120 Days & 150 Days & 180 Days \\
\hline \multicolumn{9}{|l|}{$\begin{array}{l}\text { Planting } \\
\text { dates }\end{array}$} \\
\hline $10^{\text {th }} \mathrm{Sep}$ & & & 13.38 a & 19.38 a & 25.33 a & $26.11 \mathrm{ab}$ & $30.01 \mathrm{a}$ & 30.64 a \\
\hline $1^{\text {st }}$ Oct & & & $12.84 \mathrm{ab}$ & 20.49 a & $26.52 \mathrm{a}$ & $30.46 \mathrm{a}$ & $32.95 \mathrm{a}$ & $34.41 \mathrm{a}$ \\
\hline \multirow[t]{5}{*}{$20^{\text {th }}$ Oct } & & & $12.38 \mathrm{~b}$ & $19.35 \mathrm{a}$ & 22.74 a & $25.02 \mathrm{~b}$ & $25.36 \mathrm{~b}$ & $26.53 \mathrm{~b}$ \\
\hline & $\begin{array}{l}\text { cultivar } \\
\mathbf{s}\end{array}$ & & & & & & & \\
\hline & Sids-40 & & $12.47 \mathrm{a}$ & 20.62 a & 28.76 a & $32.11 \mathrm{a}$ & 30.49 a & $34.15 \mathrm{a}$ \\
\hline & Balady & & $13.26 \mathrm{a}$ & $18.56 \mathrm{~b}$ & $20.97 \mathrm{~b}$ & $22.29 \mathrm{~b}$ & $28.39 \mathrm{a}$ & $26.90 \mathrm{~b}$ \\
\hline & & $\begin{array}{l}\text { Curing } \\
\text { periods }\end{array}$ & & & & & & \\
\hline & & 14 days & $15.21 \mathrm{a}$ & 22.49 a & 29.09 a & 30.93 a & 33.18 a & $34.03 \mathrm{a}$ \\
\hline & & 21 days & $10.52 \mathrm{~b}$ & $16.99 \mathrm{~b}$ & $20.64 \mathrm{~b}$ & $23.47 \mathrm{~b}$ & $25.71 \mathrm{~b}$ & $27.02 \mathrm{~b}$ \\
\hline
\end{tabular}

* Values having the same alphabetical letter (s) in common, within a particular group of means in each character, do not significantly differ, using the revised L.S.D. test at 0.05 level

\section{Conclusion}

Planting dates and cultivars are among the critical factors determining the yield and quality of garlic. The earlier planting of garlic will have a longer growth period before bulb initiation, resulting in larger plants producing large bulbs and yield. The Sids-40 cultivar produced the highest yield. Curing garlic for 21 days before storage resulted in better results, in lens of weight loss than those cured for 14 days.

\section{REFERNCES}

Abdel-Razzak H.S. and G.A. El-Sharkawy - (2013). Effect of Biofertilizer and Humic Acid applications on growth, yield, quality and storage ability of two garlic (Allium sativum L .) cultivars. Asian Journal of crop Science 5(1):48-64.

Abou El-Magd, M.M., T.El- Shourbagy and S.M. Shehata. (2012).A comparative study on the productivity of four Egyptian garlic cultivars growing under various organic material in comparison to conventional chemical fertilizer, Aust. J. Basic Appl.Sci.,6:415-421.

Al-Otayk ,S., El-Shinawy, M.Z, and Motawei. (2008).Variation in productive characteristics and diversity assessment of garlic cultivars and lines using DNA markers. Met.Env. Arid Land Agric .Sci.,20:63-79.

Ali.M.G.H and I.A. El-Sayed (1999). The response of two garlic varieties (Allium sativum L.) to different planting dates in the arid tropes of northern Sudan Emir .J. Agric .Sc., 11(1)31-40.

Ammar. (2007). Some studies on improving garlic productively. MR.D., Fac. Agric, and El- Mania Univ .Egypt.

Dawood, A.R., S.A Abed Elall, and A.S Badwey. (2011). Testing of some garlic (Allium sativum $L$.) cultivars under Assiut conditions Assiut J .of Agric Sci., 42(2):378-390. 
Das A.K.,M.K. Sadhu, M.G. Some and T.K, Bose. (1985).Response to varying level on N,P and $K$ on growth and yield of multiple clove garlic (Allium sativum, L) Indian Agric., 29:183- 89.

El-Zohiri, S.S.M and A.A. Farag (2014). Relation planting date , cultivars and growing degree-days on growth, yield and quality of garlic, Middle East .j. of Agric Res,3(4):1169-1183.

Fekry ,Wafaa. A. (2011). Influence of soaking cloves of Balady and Chinese garlic cultivars in some micronutrients solutions on growth, chemical composition, yield, bulb quality and storage ability. Productivity and Development Agric.Res.,16(3) (23) .

Hassan A.H.(2015). Improving growth and productivity of two garlic cultivars (Allium sativum L.) grown under sandy soil conditions .Middle East .J. . Agric 4:332-346.

Jauron R. and .G Wallace (2014):Yard and garden: Harvest, dry and store onion, garlic and shallots . Article Wed,12-15.

Mohamed, S.I.A. (2004). Some studies to improve garlic productivity, . Thesis Ph .Agric, Minia Univ ., Egypt.

Noorbakhshian, S.G.J., S.A. Mousavi and H.R. Bagheri. (2008), Evaluation of agronomic traits and path coefficient analysis of yield for garlic cultivars. Paiouhes Sazadegi ,77:10-18.

Qaryouti M.M., and M. A. Kasrawi, (1995). Storage temperature of seed bulbs and planting date influence on garlic.11yield and quality, Adv, Hort ,Sci.,9:67-70.

Rahim M.A.,M.A, Siddique, and M.M. Hassan. (1984).Effect of time of planting, mother bulb size and plant density on the yield of garlic, Bangladesh .J. Agric ,Res.,9:112-115.

Steel,R.G.D. and J.H. Torrie.(1980). Principles and Procedures of Statistics: A Biometric Approach. $2^{\text {nd }}$ End., McGraw Hill Book Co. Inc., New York, USA.,ISBN:9780070610286,Pages:633.

Subrata and, P.K. Chattopadhayay and M.A. Hassan. (2010). Dynamics of growth and yield of garlic in variable planting time and applied nutrient, Indian J. Hort, 67(3):348-352.

Swati Barche ,K.S. Kirad, A.K. Shrivastav. (2013). Effect of planting dates on growth and yield on garlic (Allium sativum L), International Journal of Horticultiral,3(4),16-18.

Yang Y.J and Lee .K.A. (2000). Effect of postharvest curing on respiration and quality of garlic bulbs during cold storage. Hort Science June ;35 no 3410 -125.

Youssef, N.S. and H.S .Tony. (2014). Influence of different planting dates on the performance of new garlic genotypes grown under El-Minia Governorate condition .Nature and Science ;12(5):4754.

Zaki, H.E.M., H.S. Toney and R.M . Abd Elraouf,. (2014). Response of two garlic cultivars (Allium sativum $L$,) to inorganic and organic fertilization. Nature and Science ;12(10):52-60. 


\section{الملخص العربي \\ تأثير مواعيد الزراعة ومدة العلاج التجفيفى على الصفات الكمية والنوعية والقدرة التخزينية لصنفين من الثوم الصفيف}

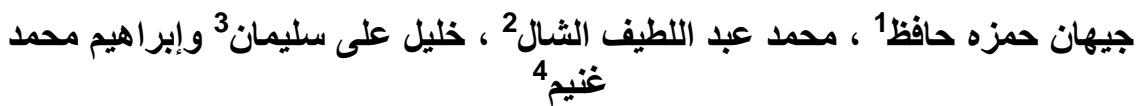

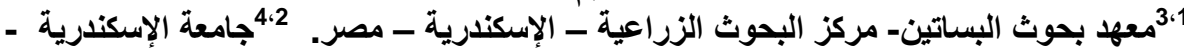

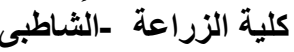

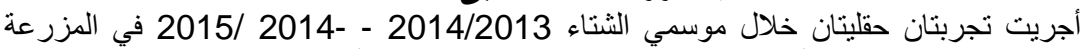

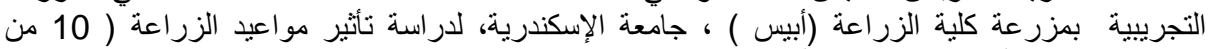

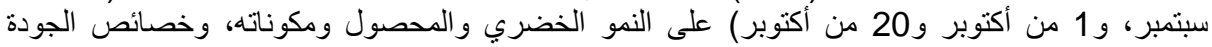

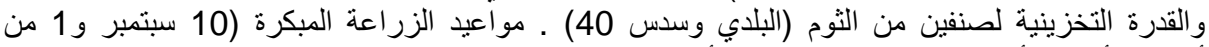

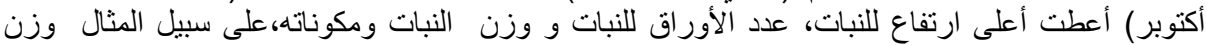

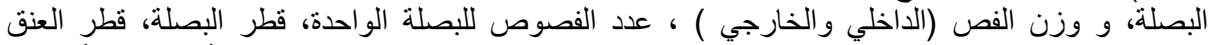

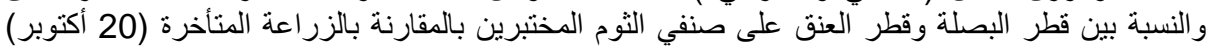

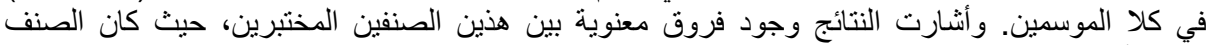

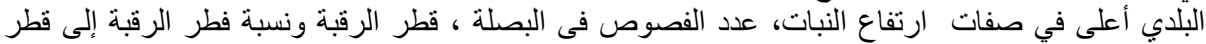

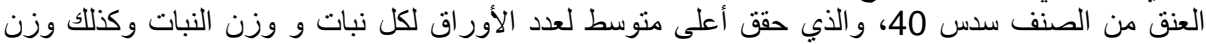

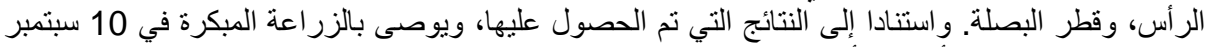

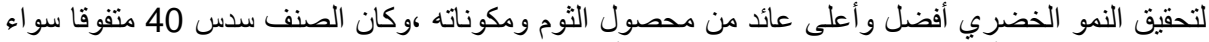

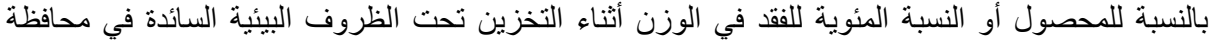

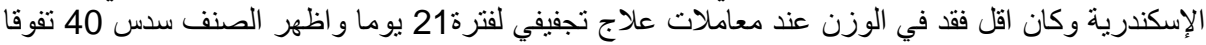

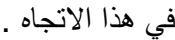

